\title{
TO THE QUESTION OF STUDYING TERRITORIAL DEMOGRAPHIC POTENTIAL
}

\author{
Kateryna SEHIDA \\ V. N. Karazin Kharkiv National University, Ukraine \\ kateryna.sehida@gmail.com
}

\begin{abstract}
Territorial resource potential acts as a basis of economic activity; therefore its rational and efficient use is one of the important directions of social and economic development of countries and regions. The demographic potential, which turned from costly factor of social development into productive one, acts as the one of the main components of the territory integral capacity. Modern scholars use different terms related to the demographic potential: human capital, human potential, human development, life potential, reproductive potential, etc. and interpret them in different ways. From the point of human geography the demographic potential is understood as a component of the territorial integral potential and human potential including features, properties and possibilities of population for permanent recovery.

There are different ways to calculate demographic potential. In our opinion, in the first approximation it must consider the characteristics of population structure and its movement. We offer to define the demographic potential as the product of a decimal logarithm of the population structure (applying weights for major age groups) and half the sum of ratios from birth and death rates and all directions migration. The proposed version of the territorial demographic potential calculation has been tested while working out the Kharkiv Region Development Strategy 2020, in particular the demographic potential of Ukrainian regions, cities and districts of Kharkiv region has been calculated.
\end{abstract}

Keywords: population, demographic potential, human potential, demographic processes, population structure.

DOI: http://dx.doi.org/10.17721/2413-7154/2016.75.21-27

UDC: 911.3

\section{ДО ПИТАННЯ ВИВЧЕННЯ ДЕМОГРАФІЧНОГО ПОТЕНЦІАЛУ ТЕРИТОРІЙ}

\section{Катерина СЕГІДА}

Харківський національний університет імені В. Н. Каразіна, Україна kateryna.sehida@gmail.com

\begin{abstract}
Анотація: Ресурсний потенціал території виступає основою господарської діяльності, тому його раціональне та ефективне використання $\epsilon$ одним із важливих напрямів соціально-економічного розвитку країн та регіонів. Одним із основних компонентів інтегрального потенціалу території виступає демографічний потенціал, який із витратного перетворився в продуктивний фактор суспільного розвитку. Сучасні науковці використовують різні споріднені до демографічного потенціалу поняття - людський капітал, людський потенціал, людський розвиток, життєвий потенціал, репродуктивний потенціал тощо та по-різному їх інтерпретують. 3 позицій суспільної географії під демографічним потенціалом розуміють складову інтегрального потенціалу території та людського потенціалу, яка включає особливості, властивості та можливості населення для постійного відновлення.

Існують різні способи обчислення демографічного потенціалу. На нашудумку, в першому приближенні він має враховувати характеристики структури населення та його руху. Демографічний потенціал пропонуємо визначати як добуток десяткового логарифму структури населення (із ваговими коефіцієнтами основних вікових груп) та напівсуми відношень народжуваності та смертності й міграції всіх напрямів. Запропонований варіант обчислення демографічного потенціалу територій було апробовано при розробці Стратегії розвитку Харківської області до 2020 року, зокрема обчислено демографічний потенціал регіонів України та міст й районів Харківської області.
\end{abstract}

Ключові слова: населення, демографічний потенціал, людський потенціал, демографічні процеси, структура населення.

DOI: http://dx.doi.org/10.17721/2413-7154/2016.76.21-27

удк: 911.3

Вступ. Ресурсний потенціал території виступає основою господарської діяльності, тому його раціональне та ефективне використання $\epsilon$ одним iз важливих напрямів соціальноекономічного розвитку країн та регіонів. За умов обмеженості фінансових засобів, зниження дієвості макроекономічних регуляторів головним ресурсом розвитку регіонів стає використання внутрішнього потенціалу території в цілому [14] та окремих його

(C) К. Сегіда складових, зокрема демографічного потенціалу, який із витратного перетворився в продуктивний фактор суспільного розвитку. Розуміння значення демографічного чинника суспільного розвитку обумовлює системний та комплексний підхід при розробці стратегій регіонального розвитку, локальних i місцевих програм соціальноекономічного розвитку [16]. Сформульоване таким чином питання має принциповий характер і вимагає аналізу та виявлення методики вивчення демографічного потенціалу території. Важливість 
дослідження обумовлює і той факт, що внутрішній потенціал України та ㄲï регіонів на сьогоднішній день $є$ недостатньо дослідженим, і регіони часто не в повному обсязі використовують його переваги та можливості.

Теоретико-методологічні основи дослідження. В математичних, економічних, соціальних, природничих науках значного поширення набуло поняття «потенціалу». У сучасній науковій літературі немає усталеного визначення поняття «демографічний потенціал». Сучасні наукові розробки вітчизняних та зарубіжних учених в даному напрямі охоплюють дослідження демографічного потенціалу, трудоресурсного потенціалу, людського потенціалу, людського капіталу, людського розвитку, життєвого потенціалу, репродуктивного потенціалу тощо. Демографічний потенціал території є типовим об'єктом суспільно-географічних досліджень, тому за мету в статті поставлено визначення сутності демографічного потенціалу території та особливостей його обчислення 3 позиції суспільної географії. Реалізація зазначеної мети зводиться до виконання наступних завдань: аналіз попередніх досліджень демографічного потенціалу та споріднених понять: людського капіталу, людського потенціалу, людського розвитку, життєвого потенціалу, репродуктивного потенціалу тощо, визначення сутності та складових демографічного потенціалу території, огляд підходів до його обчислення, обгрунтування методики обчислення демографічного потенціалу та апробація ㄲï на матеріалах районів та міст обласного підпорядкування Харківської області.

Опис методики дослідження та здобутих емпіричних даних. Активний розвиток економічних досліджень зумовив виокремлення та вивчення людського (демографічного) чинника. Поняття «людський капітал» було запропоноване Т. Шульцем як нагромаджені в країні затрати на відтворення робочої сили, результатом яких $\epsilon$ накопичення здатності людей до праці, їх утворююча діяльність в суспільстві, підтримання життя й здоров'я людей [23]. В подальшому, було розроблено та обгрунтовано теоретичну модель людського капіталу Г. Беккером, в якій відзначалось, що диференціація у ставках заробітної плати обумовлена відмінностями у індивідуальних капіталовкладеннях у робочу силу [2]. В подальшому окрім індивідуальних капіталовкладень було запропоновано враховувати індивідуальну здатність до навчання та вже існуючий рівень людського капіталу.

Дослідження людського капіталу, людського потенціалу та людського розвитку набули значної актуальності на теренах пострадянського простору. Враховуючи демографічну кризу в Україні та вичерпність демографічного потенціалу України, колективом співробітників Інституту демографії та соціальних досліджень НАН України під керівництвом провідного демографа Е. Лібанової здебільшого вивчається людський розвиток та його компоненти, чинники тощо [12]. Н. Римашевська зазначає, що саме людський потенціал $є$ сукупними можливостями суспільства і держави, які визначають могутність країни в минулому, сучасному та майбутньому; людський потенціал $\epsilon$ складною соціальноекономічною системою, його стан характеризується сукупністю показників, які доповнюють один одного: життєвий потенціал населення, інвестування у формування та нагромадження людського потенціалу, науковий потенціал суспільства, потенціал зайнятості, освітній потенціал; потенціал здоров'я; культурний потенціал. Людський потенціал являє собою, в першу чергу, можливості людського вибору, а не обсяги виробництва i відповідний рівень доходу [21]. Ключовою характеристикою демографічного потенціалу $є$ чисельність населення певної території, що, на думку К. Антипової, дозволяє у першому наближенні визначити потенціал населення певної території [1]. Іноді демографічний потенціал ототожнюють 3 людським потенціалом, тобто, розглядають кількість населення, частку працездатного населення, вікові та статеві характеристики, динаміку руху населення тощо [25].

Сучасні дослідження людського потенціалу та людського капіталу вітчизняних вчених включають показники демографічного потенціалу та трудового потенціалу. 3 позиції економістів, демографічний (демоекономічний) потенціал являє собою «сумарний додатковий продукт (різниця між обсягами вироблених i спожитих матеріальних благ та платних послуг), що буде створений усіма сучасними жителями держави протягом усього їх життя...» [13, с. 160]. Значення демографічного потенціалу та сукупної робочої сили в структурі національного багатства України було обчислено по залишковій вартості за внутрішніми цінами та світовими цінами на 1995 р. під керівництвом С. Дорогунцова [4].

В регіональній економіці, демографічний потенціал характеризуються показниками рівня суспільного розвитку, якості життя, середньої тривалості майбутнього життя, рівнем грамотності дорослого населення, обсягом ВВП на душу населення, тобто включає можливості відтворення населення і розвитку людини. Також, демографічний потенціал розуміють як сукупність знань, навичок, здібностей i мотивацій людини, що мають економічну цінність. Демографічний потенціал збільшується в результаті своєрідного інвестування (народження i виховання дітей, освіти людей, міграції населення та ін.). Демографічний потенціал розглядається в контексті ідеології людського потенціалу народонаселення, кількісний і якісний потенціали його відтворення є умовою, основою i метою розвитку суспільства і держави [6].

Соціально-демографічний потенціал розглядають як наявність та запас ресурсів населення, що здатнідосамовідтворенняівідзначаютьсямінливістю, при ефективному використанні яких забезпечується досягнення поставлених цілей, та який формують компоненти здоров'я, моралі, активності, інтелекту, організованості, освіти, професіоналізму та ресурсів робочого часу. Носієм соціально-демографічного потенціалу виступає все населення, а носієм трудового потенціалу - в основному економічно 
активне населення [3]. Існує низка дефініцій поняття «демографічний потенціал», в яких відображено вплив різних чинників. Виокремлюються різні потенціали (потенціал зростання населення П. Венсана, інерція демографічного зростання Н. Кейфіца, репродуктивний потенціал Р. Фішера та інші) [9]. Кожен 3 яких характеризує вплив певного демографічного чинника. Ці окремі потенціали можна представити як компоненти загального демографічного потенціалу. Проте зауважимо, що ці компоненти не є повністю незалежними. Наприклад, репродуктивний потенціал Р. Фішера багато в чому збігається 3 потенціалом зростання населення П. Венсана і інерцією демографічного зростання Н. Кейфіца $[9,30]$.

Розвиток демографічних досліджень зумовив необхідність визначення демографічного потенціалу. Зокрема, засновники потенційної демографії Л. Хірш та Е. Фільрозе [8] розуміли демографічний потенціал як життєвий потенціал. Вчені визначали взаємодію відтворення демографічного потенціалу та старіння населення, взаємозв'язок параметрів розвитку населення шляхом поєднання основних характеристики стабільного та реального населення. Життєвий потенціал населення України вперше обчислив С. Пирожков [20], який проаналізував динамічні та структурні зміни населення за майже сторічний період (період з 1897 по 1989 рр.). В подальшому визначення та аналіз життєвого потенціалу населення України, визначення впливу основних чинників на його динаміку проводилось співробітниками Інституту демографії та соціальних досліджень НАН України під керівництвом C. Пирожкова [15]. Співробітники Інституту економіки НАН України розуміли життєвий потенціал населення як адитивний показник, що являє собою суму життєвих потенціалів усіх, хто живе [26], а життєвий потенціал особи у певному віці визначався як середня очікувана тривалість життя у цьому віці. Повний життєвий потенціал розуміли як загальну кількість років очікуваного життя, який складається із часткових життєвих потенціалів [26]. Сучасні роботи багатьох економістів присвячені методичним та практичним аспектам оцінки життєвого потенціалу населення територій різних ієрархічних рівнів [18]. Залишаючись важливим поняттям та узагальнюючим показником потецнійної демографії, життєвий потенціал, на нашу думку, є складовою демографічного потенціалу.

Демографічний та трудовий потенціал території розрізняє Г. Федоров [7], ототожнює демографічний потенціал 3 чисельністю населення країни. А. Вишневський [29] вважає, що характеризують демографічний потенціал такі показники, як чисельність населення i його відтворення (народжуваність, смертність), вікова структура, очікувану тривалість життя, міграційний приріст, прогнози зростання населення, життєвий потенціал населення, демографічне старіння. Т. Ромашова під демографічним потенціалом розуміє показник потенційного зростання населення на основі вже сформованої статево-вікової структури і динаміки народжуваності, шлюбності та інших часткових показників [22].

Враховуючи

комплексність

суспільногеографічних досліджень, демографічний потенціал території розглядають як сукупність людських ресурсів території, як складний демографічний, соціальний, економічний, розселенський, етнічний, екологічний феномен, який відображає сукупну характеристику взаємопов'язаних ознак суспільства. Відповідно, визначають блоки оцінки демографічного потенціалу: демографічний, економікодемографічний, розселенсько-демографічний, соціально-демографічний, геодемографічний, еколого-демографічний [10].

У роботах С. Сукневої відзначається, що демографічний потенціал характеризує загальну спроможність населення регіону до відтворення, тобто постійного оновлення поколінь в результаті народження, смерті і міграції, особливо підкреслюючи роль безповоротної міграції, що суттєво впливає на структуру населення. Основними компонентами демографічного потенціалу, що знаходяться в тісному взаємозв'язку, виступають загальна чисельність населення регіону, сформовані структури населення i особливості його демографічного поведінки [28].

Математичне обгрунтування концепції демографічного потенціалу належить Д. Едієву, на думку якого, демографічний потенціал - це показник характеристики динаміки відтворення населення, а також його демографічних перспектив на агрегованому рівні. Автор акцентує увагу на демографічних перспективах, тобто, демографічний потенціал відображає не тільки поточну динаміку відтворення населення, але i передбачувану демографічну картину в майбутньому [5]. Зауважимо, що аксіоматичний підхід Д. Едісва до побудови демографічних потенціалів дозволив 3 загальних позицій підійти до розробки понять потенціалу росту, репродуктивного потенціалу i життєвого потенціалу, не обмежуючись рамками моделей 3 постійними у часі показниками народжуваності i смертності. Крім того, концепція демографічного потенціалу може бути поширена на моделі відтворення [11]. Демографічний потенціал може бути розрахований як індекс, пропорційний прямолінійній чисельності нащадків населення або його статево-віковими групами [5]. Найбільш важливе для демографічного моделювання населення властивість полягає в тому, що темп зміни сумарного демографічного потенціалу дорівнює рівномірному темпу зростання чисельності населення (істинний коефіцієнт відтворення населення). Найбільш проста реалізація концепції демо-графічного потенціалу - в рамках одностатевої моделі населення 3 постійними статево-віковими показниками народжуваності i смертності. У цьому випадку обчислення демографічного потенціалу містить у собі показники, зокрема коефіцієнт відтворення населення, народжуваності (інтенсивність народження дітей), показники дожиття (ймовірність того, що немовля доживе 
до певного віку) [11]. Чисельність населення не може бути адекватно модельована так само просто, як $\mathrm{i}$ демографічний потенціал. Зміни вікової структури i розвитку демографічних процесів роблять подібну модель спрощеною. Однак, те, що, незважаючи на свою узагальнену природу, модель адекватно відображає зміни в статево-вікової структури населення, відкриває шлях агрегованого моделювання чисельності населення. Усі ці параметри повинні бути оцінені на основі статевовікової структури моделюючого населення. Істинний коефіцієнт відтворення і очікувана тривалість життя при народженні повинні бути оцінені окремо (наприклад, як функції деяких економічних змінних). Для відкритого населення додаткові припущення повинні бути зроблені щодо міграції $[5,11]$. Таким чином, демографічний потенціал характеризується непереривністю (являється функцією віку населення) та адитивністю (являється сумою потенціалів груп населення). Розроблена концепція спирається на попередні демографічні дослідження та значно підсилює можливості використання математичного апарату в демографічних та географічних дослідженнях.

Суспільно-географічний підхід дозволяє розглядати демографічний потенціал як складову інтегрального потенціалу території, в структурі якого інтегрального потенціалу виділяється низка часткових потенціалів, які пов'язані з наявністю на території певних видів ресурсів та їх груп, провідна роль у складі інтегрального потенціалу належить саме людському потенціалу, який включає демографічний, працересурсний та екістичний [19]. Ми погоджуємось із співробітниками Інституту географії НАН України, що демографічний потенціал витупає важливою складовою людського потенціалу, що включає всі особливості, властивості та можливості населення, необхідні для відновлення поколінь, тобто чисельності населення 3 його структурою та якісними характеристиками. Запропонована методика обчислення демографічного потенціалу враховує такі показники: динаміка чисельності населення, демографічна структура, демографічні процеси та міграції [19].

Розуміння значущості демографічного потенціалу як основи розвитку території пояснює необхідність врахування його особливостей про створенні програм регіонального розвитку, тим більше, важливим залишається визначення демографічного потенціалу низових адміністративних одиниць, що дасть змогу встановити внутрішньорегіональні особливості та виробляти адаптовані заходи регіональної політики. Адже територіальна диференціація соціальноекономічного потенціалу відображає особливості системи розселення. Відповідно, формування програм соціально-економічного розвитку, які безпосередньо орієнтуються на наявний природоресурсний, трудоресурсний, виробничий, інвестиційний та інші види потенціалів, мають враховувати демографічний потенціал, адже зрозуміло, що населення залишається головним виробником та споживачем всіх матеріальних та нематеріальних товарів й послуг. Тому вироблення конкретних задач соціально-економічного розвитку має проводитись із урахуванням демографічних особливостей, які $є$ результатом i відображенням історико-географічного та соціально-економічного розвитку, а також впливовим чинником суспільного розвитку [16].

Існують різні способи обчислення демографічного потенціалу, на нашу думку, в першому приближенні він має враховувати характеристики структури населення та його руху. Було запропоновано індикатор демографічного розвитку [17, 24], який включав себе інформацію про зміни чисельності населення шляхом природного ті міграційного рухів і визначається як середнє арифметичне співвідношення основних демографічних показників: народжуваності і смертності, прибулих і вибулих в межах області, прибулих і вибулих за їі межами:

$$
I_{\text {дем. розв. }}=1 / 3\left(\frac{K_{\text {нар }}}{K_{C M .}}+\frac{K_{\text {вн } n p .}}{K_{\text {вн вนб. }}}+\frac{K_{\text {зовн } n p .}}{K_{\text {зовн вนб. }}}\right),
$$

де $K_{\text {нар. }}-$ коефіцієнт народжуваності, $K_{c м}-$ коефіцієнт смертності, $K_{\text {вн.nр. }}$ - коефіцієнт прибулих в межах області, $K_{\text {вн.виб }}-$ коефіцієнт вибулих в межах

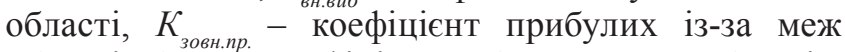

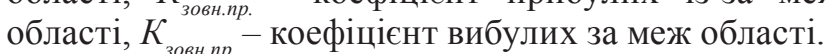

Основою демографічного потенціалу виступає структура населення, але зрозуміло, що «вклад» населення старшої та молодшої вікових груп є різним, тому доцільно ввести вагові коефіцієнти, зокрема 0,3 для групи населення до 14 років, 0,5 - для групи населення 15-64, 0,2 - для групи населення старших за 64 роки. Оскільки, конструювання запропонованого індикатора має відповідати вимозі визначення демографічного потенціалу різних територій, чисельність населення яких також є досить різною, варто структуру населення в індикатор вводити через десятковий логарифм. Значення руху населення для демографічного потенціалу $€$ меншим за значення структури, тому вважаємо за потрібне ввести ваговий коефіцієнт 0,5, а показник руху, виходячи із коефіцієнту демографічного розвитку, обчислювати як суму відношень народжуваності та смертності й міграції (всіх напрямів). Таким чином, демографічний потенціал можна представити як:

$$
\text { Д.п. }=\cdot \operatorname{Lg}\left(0,3 \mathrm{xK}_{0-14}+0,5 \mathrm{xK}_{15-64}+0,2 \mathrm{xK}_{65+}\right) \cdot \mathrm{x} \cdot 0,5\left(\frac{\kappa_{\text {нар }}}{\kappa_{\text {сM }}}+\frac{\kappa_{\text {мirp }}}{K_{\text {мirp- }}}\right) \text { : }
$$

де $K_{0-14}$ - вікова група до 14 років, $\mathrm{K}_{15-64}$ - вікова група 15-64 років, $K_{64+}$ - вікова група старше 65 років, $K_{\text {нар }}$ - коефіцієнт народжуваності, $K_{c м}-$ коефіцієнт смертності, $K_{\text {мігр⿱ }}-$ інтенсивність прибуття, $K_{\text {мігр- }}-$ інтенсивність вибуття.

Запропонований варіант обчислення демографічного потенціалу територій було апробовано при розробці Стратегії розвитку Харківської області до 2020 року [27], зокрема обчислено демографічний потенціал регіонів України та міст й районів Харківської області. Для прикладу наведено вихідні дані та розрахований демографічний потенціал районів та міст обласного підпорядкування 
Таблиия 1

Демографічний потенціал міст та районів Харківської області

\begin{tabular}{|c|c|c|c|c|c|c|c|c|}
\hline & $\begin{array}{c}\text { Кількість } \\
\text { осіб у } \\
\text { віці 0-14 } \\
\text { (осіб) }\end{array}$ & $\begin{array}{c}\text { Кількість } \\
\text { осіб у } \\
\text { віці 15-64 } \\
\text { (осіб) }\end{array}$ & $\begin{array}{c}\text { Кількість } \\
\text { осіб у } \\
\text { віці } 65 \text { і } \\
\text { старше } \\
\text { (осіб) }\end{array}$ & $\begin{array}{c}\text { Коеф. } \\
\text { народжу- } \\
\text { ваності } \\
\text { (проміле) }\end{array}$ & $\begin{array}{c}\text { Коеф. } \\
\text { смерт- } \\
\text { ності } \\
\text { (проміле) }\end{array}$ & $\begin{array}{l}\text { Інтенсив- } \\
\text { ність } \\
\text { прибуття } \\
\text { (проміле) }\end{array}$ & $\begin{array}{c}\text { Інтенсив- } \\
\text { ність } \\
\text { вибуття } \\
\text { (проміле) }\end{array}$ & $\begin{array}{c}\text { Демогра- } \\
\text { фічний } \\
\text { потенціал }\end{array}$ \\
\hline м.Харків & 168048 & 1055868 & 207649 & 9,1 & 11,7 & 19,5 & 16,8 & 5,61 \\
\hline м.Ізюм & 6555 & 35913 & 8724 & 8,3 & 18,3 & 14,3 & 10,8 & 3,85 \\
\hline м.Куп'янськ & 7840 & 41280 & 8528 & 9,4 & 17 & 22,2 & 21,8 & 3,45 \\
\hline м.Лозова & 9189 & 49574 & 8961 & 10 & 14 & 10,2 & 12,8 & 3,38 \\
\hline м.Люботин & 3427 & 16877 & 4252 & 9 & 18,5 & 20,5 & 12,9 & 4,16 \\
\hline м.Первомайський & 4467 & 22464 & 4416 & 10,6 & 14,5 & 19,0 & 17,5 & 3,75 \\
\hline м.Чугуїв & 5048 & 23411 & 4434 & 11 & 15,2 & 20,8 & 13,4 & 4,73 \\
\hline Балаклійський & 11522 & 58324 & 13466 & 10,6 & 17,4 & 16,3 & 15,1 & 3,84 \\
\hline Барвінківський & 3512 & 15418 & 4467 & 11,1 & 20,6 & 3,7 & 19,9 & 1,44 \\
\hline Близнюківський & 3080 & 13107 & 3574 & 12,2 & 21,1 & 13,6 & 25,4 & 2,18 \\
\hline Богодухівський & 5754 & 27341 & 6713 & 11 & 18,4 & 17,8 & 15,2 & 3,74 \\
\hline Борівський & 2591 & 11806 & 2983 & 10,7 & 16,9 & 20,5 & 20,4 & 3,16 \\
\hline Валківський & 4462 & 22121 & 5764 & 10,3 & 19,3 & 19,8 & 13,1 & 4,22 \\
\hline Великобурлуцький & 3522 & 15649 & 3890 & 9,3 & 18,3 & 15,3 & 19,7 & 2,56 \\
\hline Вовчанський & 6651 & 32240 & 8511 & 9,5 & 19,2 & 14,3 & 12,6 & 3,50 \\
\hline Дворічанський & 2705 & 12336 & 3236 & 9,9 & 19,1 & 15,8 & 19,1 & 2,61 \\
\hline Дергачівський & 13310 & 66875 & 14981 & 10,5 & 16,6 & 16,7 & 10,2 & 5,23 \\
\hline Зачепилівський & 2427 & 10632 & 2724 & 10,5 & 19 & 9,9 & 15,6 & 2,27 \\
\hline Зміївський & 10004 & 48910 & 13413 & 10,5 & 18 & 14,1 & 9,7 & 4,57 \\
\hline Золочівський & 3943 & 17653 & 5175 & 12,1 & 20,2 & 12,5 & 10,4 & 3,64 \\
\hline Ізюмський & 2543 & 12235 & 3394 & 9,2 & 21,2 & 18,0 & 16,6 & 2,94 \\
\hline Кегичівський & 3576 & 14612 & 3140 & 11,5 & 16,5 & 12,6 & 17,6 & 2,80 \\
\hline Коломацький & 1149 & 4528 & 1621 & 11,3 & 19,8 & 5,4 & 17,4 & 1,53 \\
\hline Красноградський & 6417 & 31577 & 7259 & 10,5 & 15,3 & 20,3 & 19,4 & 3,71 \\
\hline Краснокутський & 4294 & 19127 & 5315 & 11,3 & 20,2 & 17,2 & 16,0 & 3,34 \\
\hline Куп’янський & 3430 & 17112 & 5039 & 10,2 & 19,7 & 21,2 & 21,6 & 3,02 \\
\hline Лозівський & 4513 & 20480 & 5020 & 11,6 & 16,8 & 10,0 & 13,9 & 2,89 \\
\hline Нововодолазький & 5236 & 22977 & 5826 & 11,4 & 19,2 & 11,4 & 11,5 & 3,28 \\
\hline Первомайський & 2205 & 10709 & 3557 & 9,9 & 20,6 & 20,3 & 22,5 & 2,65 \\
\hline Печенізький & 1367 & 6804 & 2177 & 9,5 & 19,1 & 14,5 & 10,6 & 3,38 \\
\hline Сахновщинський & 3409 & 14898 & 3907 & 11,1 & 17,6 & 14,2 & 17,0 & 2,91 \\
\hline Харківський & 24687 & 131902 & 25974 & 10,8 & 16 & 17,6 & 14,8 & 4,56 \\
\hline Чугуївський & 6569 & 32479 & 7957 & 11,1 & 16,8 & 20,0 & 12,7 & 4,81 \\
\hline Шевченківський & 3170 & 14199 & 3499 & 10,4 & 16,2 & 16,9 & 19,6 & 2,97 \\
\hline
\end{tabular}

Харківської області (табл. 1). Відповідно до середнього значення демографічного потенціалу було виділено групи міст і районів [27, с.24], що дало змогу встановити територіальну диференціацію демографічного потенціалу в межах області. Найвище значення демографічного потенціалу у м. Харкові, Дергачівському та Чугуївському районах. Вище середнього демографічний потенціал у Харківському, Зміївському та Валківському районах, мм. Люботин та Чугуїв. Харківщина має моноцентричну модель розселення населення, відповідно, i демографічний потенціал їй відповідає: обласний центр концентрує більше половини населення та економічного потенціалу, соціально-економічний розвиток зазначених міст та районів відбувається під впливом м. Харкова завдяки географічному положенню. Найнижчі показники демографічного потенціалу у Коломацькому, Близнюковському та Барвінківському районах, які є периферійними та депресивними.
Оцінка та обговорення результатів, висновки. Демографічний потенціал виступає основою соціально-економічного розвитку, саме тому формування заходів регіональної політики має спиратись за наявний потенціал, враховувати демографічні особливості територій тощо. Розуміння значення демографічного чинника суспільного розвитку обумовило вивчення демографічного потенціалу вченими різних наук. В залежності від об’єктно-предметного поля дослідження науки змішуються акценти в трактуванні демографічного потенціалу. Зокрема, економісти здебільшого вивчають демоекономічний потенціал, трудоресурсний потенціал, людський капітал тощо, тобто 3 огляду на економічні можливості використання ресурсу населення; демографи здебільшого акцентують увагу на дослідженнях репродуктивних можливостей населення, вивчають життєвий потенціал, потенціал демографічного зростання та відтворення тощо. Дослідження 
демографічного потенціалу територій лежить в об’єктно-предметному полі суспільної географії. На нашу думку, саме суспільно-географічний підхід дає змогу комплексного вивчення ресурсних можливостей територій, пошук причин та наслідків територіальної диференціації демографічних процесів та розселення населення, що і обумовлює особливості демографічного потенціалу, які необхідно враховувати при розробці заходів регіональної політики. Існують різні підходи до обчислення демографічного потенціалу. Запропоновано визначення демографічного потенціалу території як добуток десяткового логарифму структури населення (iз ваговими коефіцієнтами основних вікових груп) та напівсуми відношень народжуваності та смертності й міграції всіх напрямів. Запропонований варіант обчислення демографічного потенціалу не є універсальним, проте є зручним інструментом для визначення показника в першому наближені, що дало змогу наочно відобразити його територіальні відмінності. Запропонований варіант обчислення демографічного потенціалу територій було апробовано при розробці Стратегії розвитку Харківської області до 2020 року, зокрема обчислено демографічний потенціал регіонів України та міст й районів Харківської області, що наведено як приклад в статті. Проте ми розуміємо, що демографічний потенціал $є$ містким поняття, перебуває під впливом ряду процесів та може включати в себе й інші демографічні характеристики, існує потужне математичне обгрунтування його обчислення за умови різних моделей населення та врахування ряду показників, що в подальших дослідженнях буде розглянуто.

\section{References:}

1. Antipova E. Opyt ispol'zovaniâ GIS-tehnologij v geografii naseleniâ [Experience of GIS technology use in geography of population]. Vestnik Belorusskogo gosudarstvennogo universiteta, Serija 2 [Journal of Belarusian State University. Series 2.]., 2007, №2, s. 87-93.

2. Becker G. S. Human Capital: A Theoretical and Empirical Analysis with Special Reference to Education. Chicago, London: The University of Chicago Press, 1992, $361 \mathrm{p}$.

3. Bìl' M. M. İntelektual'na komponenta socìal'no-demografǐčnogo potencìalu: upravlìns'kì pìdhodi do efektivnostì vikoristannâ na makrorìvnì [The intellectual component of socio-demographic potential: management approaches to efficiency at the macro level]. Bûleten' Mižnarodnogo Nobelìvs'kogo ekonomičnogo forumu [Bulletin of the International Nobel Economic Forum], 2011, N. 1(4), pp. 51-56 (In Ukrainian).

4. Dorohuntsov S. I. (Ed.) Nacional'ne bagatstvo Ukraïni [The national wealth of Ukraine]. Kyiv, 2005,224 p. (In Ukrainian).

5. Ediev D. M. Application of the demographic potential concept to understanding the Russian population history and prospects: 1897-2100. Demographic Research. 2001, Vol. 4, Article 9, pp. 289-336.

6. Fauzer V. G. Demografičeskij potencial severnyh regionov Rossii kak faktor èkonomičeskogo osvoeniâ Arktiki [The demographic potential of the northern regions of Russia as a factor of economic development of the Arctic]. Arktika i Sever [Arctic and North], 2013, N. 10, pp. 1-29. (In Russian).

7. Fedorov G. M. Geodemografičeskaâ obstanovka: teoretičeskie i metodičeskie osnovy [Geo-demographic situation: theoretical and methodological foundations]. Leningrad, 1984, 112 p. (In Russian).

8. Fil'roze È.Očerk potencial'noj demografii [Outline of potential demography]. Moscow, 1975, 215 p.

9. Fisher R. A. The genetical theory of natural selection. N-Y.: Dover Publications, 1930, 291 p.

10. Gabdrahmanov N. K. Demografičeskij potencial Respubliki Tatarstan: analiz, ocenka, territorial'nye različiâ [The demographic potential of the Republic of Tatarstan: the analysis, evaluation, territorial differences]. Vestnik Udmurtskogo Universiteta [Bulletin of Udmurt University], 2012, 1-6, pp. 145-155. (In Russian).

11. Èdiev D. M. Koncepciâ demografičeskogo potenciala i ee priloženiâ [The concept of demographic potential and its applications]. Access mode: http://www.mathnet.ru/php/archive.phtml?wshow=paper\&jrnid=mm\&paperid=3 65\&option_lang=rus (In Russian).

12. Lì̄anova E. M. (Ed.) Lûds'kij rozvitokv Ukraïnì: ìnnovacìjnij vimìr [Human development in Ukraine: an innovative dimension]. Kyiv, 2008, 383 p. (In Ukrainian).

13. Makarova O. V., Poznâk O. V. Metodika vartìsnoï ocìnki demoekonomìcnogo potencìalu [The method of demo-economic potential evaluation]. Zajnâtìst' ta rinok pracì [Employment and labor market], 1998, Vol. 6, pp. 160167. (In Ukrainian).

14. Nagìrna V. P. İntegral'nij potencìal teritorïi u kontekstì gospodars'koï diâl'nostì teritoriï [Integral potential of the territory in the context of economic territory]. Ukrä̈ns'kij geografičnij žurnal [Ukrainian Geographical Journal], 2010, Vol. 2, pp. 32-39. (In Ukrainian).

15. Naselennya Ukrayiny: 2003. Shchorichna analitychna dopovid' [Ukrainian Population in 2003: Annual analytical report]. Kyiv, 2004, 252 p. (In Ukrainian).

16. Niemets' L., Sehida K., Guseva N. Demographic potential as the basis for social and economic development. Ekonomičnij časopis - XXI [Economic Annals-XXI], 2015, N. 3-4, C.93-97.

17. Nyemets' L. M., Sehida K. Yu., Nyemets' K. A. Demografičnij rozvitok Harkìvs'kogo regìnu [Demographic development of the Kharkiv region]. Kharkiv, 2012, 200 p. (In Ukrainian).

18. Pìdgornij A. Z., Vìtkovs’ka K. V. Deâkì metodologìcnì aspekti ocìnki žittêvogo potencìalu naselennâ na 
regìonal'nomu rìvnì [Some methodological aspects of assessing potential public life at regional level]. Visnik socìal'noekonomičnih doslìdžen' [Journal of Social and Economic Research], 2008, Vol. 30, pp. 308-314. (In Ukrainian).

19. Pìdgrušnij G. P., Nagìrna V. P., Faŝevs'kij M. İ., Kačaêv Û. D., Pašins’ka N. M., Denisenko O. O., Savčuk Ì. G., Šabašova L. .Û., Nemčenko M. P., Bondar V. V. Suspil'no-geografičnì osnovi doslìdžennâ ìntegral'nogo potencìalu teritoriii: teoretiko-metodologičnì pìdhodi ta dosvìd ocìnki [Socio-geographical bases of research of integral territorial capacity: theoretical and methodological approaches and assessment experience]. Ukraïns'kij geografičnij žurnal [Ukrainian Geographical Journal], 2011, Vol. 3, pp. 42-48. (In Ukrainian).

20. Pirožkov S. I. Trudovoj potencial $v$ demografičeskom izmerenii [Labour potential in the demographic dimension]. Kyiv, 1992, 180 p. (In Russian).

21. Rimaševskaâ N. Kačestvo čelovečeskogo kapitala v Rossii [The quality of human capital in Russia], Moscow, 2009, 112 p. (In Russian)

22. Romashova T. V. Vvedenie vèkonomičeskûu $i$ social'nûu geografiû [Introduction to the economic and social geography]. Moscow, 2006, 240 p. (In Russian)

23. Schultz T. Investments in Human Capital. The American Economic Review, 1961, N. 51 (1), pp. 9-27.

24. Segìda K. Û., Nêmec' L. M., Nêmec' K. A. Kompleksnij ìndikator demografičnogo rozvitku regìonal'noï socìogeosistemi (na prikladì Harkìvs'koï oblastì) [Demographic indicator of regional social geographic system (the case of Kharkiv Region)]. Zbirnyk naukovykh prats" "Visnyk Kharkivs'koho natsional'noho universytetu imeni V.N. Karazina: Heolohiya - Heohrafiya - Ekolohiya» [Collected Works "Bulletin of Kharkiv National University: GeologyGeography-Ecology”], 2011, N. 986, pp. 166-171. (In Ukrainian).

25. Starostenko H. H., Oniško S. V., Posnova T. V. Natsional'na ekonomika [National economy]. Kyiv, 2011, 432 p. (In Ukrainian).

26. Stešenko V., Rudnic'kij O., Homra O., Stefanovs'kij A. Demografičnì perspektivi Ukraïni do 2026 roku [Demographic prospects for Ukraine in 2026]. Kyiv, 1999, 55 p. (In Ukrainian).

27. Strategiâ rozvitku Harkivs'koï oblastì na perìd do 2020 roku [Kharkiv Region development strategy until 2020]. Access mode: kharkivoda.gov.ua/documents/16203/1088.pdf (In Ukrainian).

28. Suknëva S. A. Demografičeskij potencial vosproizvodstva naseleniâ Severnogo regiona (na primere Respubliki Saha (Âkutiâ)) [The demographic potential of population reproduction of the Northern region (on the example of the Republic of Sakha (Yakutia))]. Abstract from PhD Thesis. Moscow, 2011, 43 p. (In Russian).

29. Višnevskij A. G. Vosproizvodstvo naseleniâ i obŝstvo: Istoriâ, sovremennost', vzglâd v buduŝee [The reproduction of the population and society: history, the present, the future.]. Moscow, 1982, 287 p. (In Russian).

30. Wachter K. W. Age group growth rates and population momentum. Population Studies. Vol. 42, 1988, p. 487494. 